\title{
Analysis of the critical factors for integration of sustainability with lean practices for Indian manufacturing enterprises
}

\section{Sonal Khurana*}

Department of Mechanical Engineering, Maharaja Agrasen Institute of Technology,

Delhi-110085, India

Email: sonal.khurana@gmail.com

*Corresponding author

\section{Bisma Mannan}

Department of Mechanical Engineering,

Sharda University,

UP-201310, India

Email: bismamannan@gmail.com

\section{Abid Haleem}

Department of Mechanical Engineering,

Jamia Millia Islamia,

Delhi-110025, India

Email: haleem.abid@gmail.com

\begin{abstract}
Lean production is stated as a business structure which helps to organise and manage product development, operations, suppliers, and consumer association. It is done with reduced human attempt, reduced area, reduced money, reduced material, and reduced time taken to manufacture parts with not many defects to fulfil consumer expectations, in contrast to the earlier arrangement of mass production. Sustainable manufacturing is stated as the building of manufactured parts which utilise procedures that are non-polluting, preserve energy and natural resources, and are cost effective and there is safety for employees, communities, and customers. ISM has been used to identify and summarise interconnection among specific variables that states a problem. It presents us with a method through which order may be set on the variables. It is followed by the MICMAC analysis which has been performed with the help of the specified variables. Financial factor and government rules and regulations' have been identified as variables having highest driving power.
\end{abstract}

Keywords: lean; interpretive structural modelling; micro, small and medium scale industries; MSMEs; MICMAC; sustainable manufacturing.

Reference to this paper should be made as follows: Khurana, S., Mannan, B. and Haleem, A. (2020) 'Analysis of the critical factors for integration of sustainability with lean practices for Indian manufacturing enterprises', Int. J. Forensic Engineering and Management, Vol. 1, No. 1, pp.116-123. 
Biographical notes: Sonal Khurana is working as an Assistant Professor in the Maharaja Agrasen Institute of Technology, Delhi. She obtained her BTech in Mechanical and Automation Engineering from the GGSIPU and completed her MTech in Industrial and Production Engineering from the Jamia Millia Islamia. She was awarded a Gold medal at her MTech level. She has completed her PhD in Industrial Engineering. She also has published a book with Lambert publishing house. Her papers have been published in many national and international conferences. One of her papers got published in Journal of Cleaner Production. Her research interest includes green practices, sustainable oriented innovation, sustainable manufacturing, technology management, operations management among others.

Bisma Mannan is working as an Assistant Professor in the Sharda University. She completed her Doctorate from the Jamia Millia Islaimia. She has published a book with LAP Publication, Germany. Her papers were published in three national conferences and six international conferences. One of her paper published in IJCA, USA. Her research interest includes innovation, green practices, knowledge management, technology management, robotics applications area among others.

Abid Haleem is a Professor and a former Head of Mechanical Engineering Department at the Faculty of Engineering and Technology, and also the Honorary Director of Internal Quality Assurance Cell (IQAC) Jamia Millia Islamia (A Central University by an Act of Parliament), New Delhi, India. He obtained his PhD from IIT (Delhi) in the area of Strategic Management. He was awarded Gold medal at post graduation level. He has more than a hundred research papers to his credit, published in international and national journals. He has authored a book titled Innovation, Flexibility and Technology Transfer, published by Tata McGraw Hill, India. He is also Regional Editor in the Asia Pacific Region, for Global Journal of Flexible Systems Management. He has produced many PhDs and seven students are enrolled with him for their research work under his guidance.

This paper is a revised and expanded version of a paper entitled 'Analysis of the critical factors for integration of sustainability with lean practices for Indian manufacturing enterprises' presented at 15th International Ergonomics Conference on Humanizing Work and Work Environment (HWWE 2017), Aligarh Muslim University, Aligarh (UP), 8-10 December 2017.

\section{Introduction}

In 1987, a report published by Bruntland Commission 'Our common future' aimed to connect the matter of economic progress and environmental balance. In that process, the definition of sustainable development was provided as, "development that can meet the requirement of the present without compromising the ability of future generations to meet their requirements." Sustainability can also be described as the task to decrease the unfavourable consequences on people and environment and also improving value for consumers and other stakeholders (Khurana et al., 2014). In today's scenario, many firms have taken the initiative to move in the direction of incorporating sustainably aligned practices. The current research considers all the three dimensions of sustainability into consideration. 
Lean production is stated as a business structure which helps to organise and manage product development, operations, suppliers, and consumer association. It is done with reduced human attempt, reduced area, reduced money, reduced material, and reduced time taken to manufacture parts with not many defects to fulfil consumer expectations, in contrast to the earlier arrangement of mass production. Sustainable manufacturing is stated as the building of manufactured parts which utilise procedures that are non-polluting, preserve energy and natural resources, and are cost effective and there is safety for employees, communities, and customers. MSMEs form an important part of industrial enterprises and provide huge employment potential.

Taking into consideration the above, the important issues which concerns MSMEs in their drive towards integration of sustainability with lean practices for manufacturing MSMEs of India are as follows:

Factors which affect the integration of sustainability with lean practices for Indian manufacturing MSMEs? To identify the factors which have high driving power and factor which has high driven power.

\section{Factors affecting integration of sustainability with lean practices}

Lean manufacturing system implementation variables are as follows.

These factors have been chosen after a thorough discussion with the subject experts. Typically these complex set of factors were additionally examined with the help of a number of information exchange with the knowledgeable persons of the concerned fields to set the inter-relation amongst these factors.

\section{Methodology}

\subsection{Interpretative structural modelling}

Interpretative structural modelling (ISM) is used to identify and summarise interconnections amidst specified variables that state a problem or a point. It presents us with a method by which order can be set on specified variables (Kumar et al., 2013a; Mannan et al., 2012; Haleem et al., 2012; Kumar et al., 2013b). The ISM is explanatory as the understanding of the experts determines as in what way the factors are associated with each other. This approach is formative based on association; complete formation is obtained from the given set of variables. ISM is an approach used to make a model where the particular associations and complete formation are depicted in a framework graphically.

The procedure elaborated in the ISM approach is as follows.

1 Recognising factors that are appropriate to the problem or issues, it is performed by any group problem solving approach.

2 Setting up a circumstantial association among elements relative to which pair of elements can be analysed.

3 To develop a structural self-interaction matrix (SSIM) of elements that depicts pairwise association among elements of the system. 
4 To develop a reachability matrix with the help of the SSIM, and to check the matrix for transitivity - transitivity of the contextual association is a fundamental presumption in ISM that tells if element $\mathrm{A}$ is associated with $\mathrm{B}$ and $\mathrm{B}$ is associated with $\mathrm{C}$, then $\mathrm{A}$ is associated with $\mathrm{C}$.

5 Partition the reachability matrix into various levels.

6 On the basis of association given above in the reachability matrix, a directed graph (digraph) is drawn, and the transitive links are removed.

7 The resultant digraph is converted into an ISM-based framework by substituting element nodes with the statement.

8 Analyse the framework to check for theoretical deviation and do the needed changes.

ISM approach is employed to find dependent association amongst different variables. A model is established from ISM approach. 'Organisation structure and organisation culture' are recognised as top-level variables and 'financial factor and government rules and regulations' have been identified as bottom level variables.

Table 1 Table of the critical factors taken from the literature review

\begin{tabular}{|c|c|c|c|}
\hline S. no. & Factors & Description & References \\
\hline 1 & $\begin{array}{l}\text { Financial } \\
\text { factor }\end{array}$ & $\begin{array}{c}\text { Financial resources help the firm in } \\
\text { investing in the sustainable lean } \\
\text { practices. }\end{array}$ & $\begin{array}{c}\text { Khurana et al. (2014), Xie } \\
\text { et al. (2013), Lecerf (2012), } \\
\text { Pedram (2011) and Emiliani } \\
\text { (2001) }\end{array}$ \\
\hline 2. & $\begin{array}{l}\text { Consumer } \\
\text { preference }\end{array}$ & $\begin{array}{l}\text { Consumer preference encourages } \\
\text { the firm to adapt the sustainable } \\
\text { lean practices. }\end{array}$ & $\begin{array}{c}\text { Subrahmanya (2015) and } \\
\text { Pingyu and Yu (2010) }\end{array}$ \\
\hline 3 & $\begin{array}{l}\text { Organisation } \\
\text { structure }\end{array}$ & $\begin{array}{c}\text { Proper organisation structure helps } \\
\text { in easy adoption of sustainable lean } \\
\text { practices. }\end{array}$ & $\begin{array}{c}\text { Cuerva et al. (2014) and Dixit } \\
\text { et al. (2011). }\end{array}$ \\
\hline 4 & $\begin{array}{l}\text { Employee } \\
\text { training }\end{array}$ & $\begin{array}{l}\text { Employee training will smoothen } \\
\text { the process of transformation } \\
\text { towards sustainable lean practices. }\end{array}$ & $\begin{array}{l}\text { Khurana et al. (2014), Dixit } \\
\text { et al. (2011) and Jones and } \\
\text { Zubielqui (2016) }\end{array}$ \\
\hline 5 & Firm size & $\begin{array}{l}\text { Adequate firm size will help in } \\
\text { giving proper training to each } \\
\text { employee to move in this direction. }\end{array}$ & $\begin{array}{l}\text { Subrahmanya (2015), } \\
\text { Teleghani (2010), O'Cass and } \\
\text { Weerawardena (2009) and } \\
\text { Fagerberg (2005) }\end{array}$ \\
\hline 6 & $\begin{array}{l}\text { Organisation } \\
\text { culture }\end{array}$ & $\begin{array}{l}\text { Good organisation culture will } \\
\text { motivate the employees to move in } \\
\text { the direction of sustainable lean } \\
\text { practices. }\end{array}$ & $\begin{array}{l}\text { Pedram (2011), Cuerva et al. } \\
\text { (2014), Teleghani (2010) and } \\
\text { Mannan and Khurana (2012) }\end{array}$ \\
\hline 7 & $\begin{array}{l}\text { Government } \\
\text { rules and } \\
\text { regulations }\end{array}$ & $\begin{array}{l}\text { Favourable government regulations } \\
\text { will work as an incentive for the } \\
\text { firms to move in this direction. }\end{array}$ & $\begin{array}{c}\text { Pedram (2011), } \\
\text { Kunapatarawong and } \\
\text { Martínez-Ros (2016), Luthra } \\
\text { et al. (2015) and Bergek et al. } \\
\text { (2014) }\end{array}$ \\
\hline 8 & $\begin{array}{l}\text { Environmental } \\
\text { concern }\end{array}$ & $\begin{array}{l}\text { Environmental concern motivates } \\
\text { the firm to shift towards sustainable } \\
\text { lean practices. }\end{array}$ & $\begin{array}{c}\text { Pingyu and Yu (2010), } \\
\text { Cuerva et al. (2014) and } \\
\text { Jones and Zubielqui (2016) }\end{array}$ \\
\hline
\end{tabular}


Table 2 Final level partitioning

\begin{tabular}{lcccc}
\hline Variable & Reach ability set & Antecedent set & Intersection set & Level \\
\hline 3 & 3,6 & $1,2,3,4,5,6,7,8$ & 3,6 & Level 1 \\
6 & 3,6 & $1,2,3,4,5,6,7,8$ & 3,6 & Level 1 \\
4 & 4,5 & $1,2,4,5,7,8$ & 4,5 & Level 2 \\
5 & 4,5 & $1,2,4,5,7,8$ & 4,5 & Level 2 \\
2 & 2 & $1,2,7,8$ & 2 & Level 3 \\
8 & 8 & $1,7,8$ & 8 & Level 4 \\
1 & 1,7 & 1,7 & 1,7 & Level 5 \\
7 & 1,7 & 1,7 & 1,7 & Level 5 \\
\hline
\end{tabular}

\subsection{MICMAC analysis}

MICMAC analysis involves building of a graph to categorise identified factors which helps in integration of sustainability with lean practices based on their driving and dependence power (Luthra et al., 2015).

Figure 1 ISM model

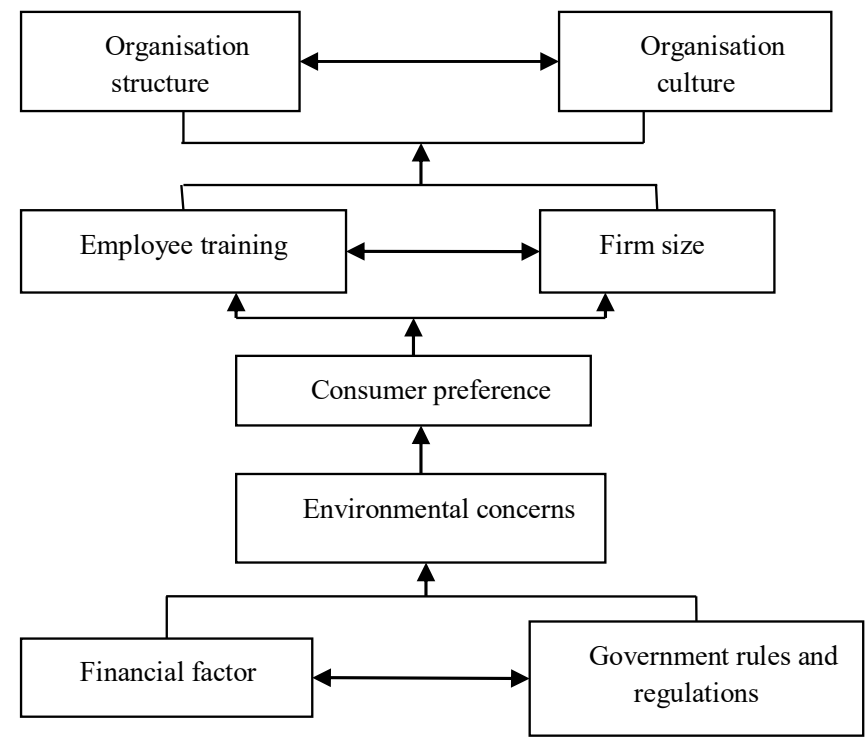

Source: Author's own elaboration

The first set is composed of the independent variables that are weakly dependent and have low driver power. There is not a single variable that is recognised as independent variable. Second set is having the variables that are having low driver power but high dependent power. Organisation structure, employee training, firm size and organisation culture are recognised as dependent variables. Third set has the linkage variables that consist of variables that are having high driver power and also are strongly dependent. There is no variable that is recognised as linkage variable in our research. Last set 
consists of the independent variables that have high driving power but low dependent power. Financial factor, consumer preference, government rules and regulations and environmental concern have been identified (see Figure 2).

Figure 2 MICMAC analysis of various factors to integrate sustainability with lean practices for Indian manufacturing enterprises (see online version for colours)

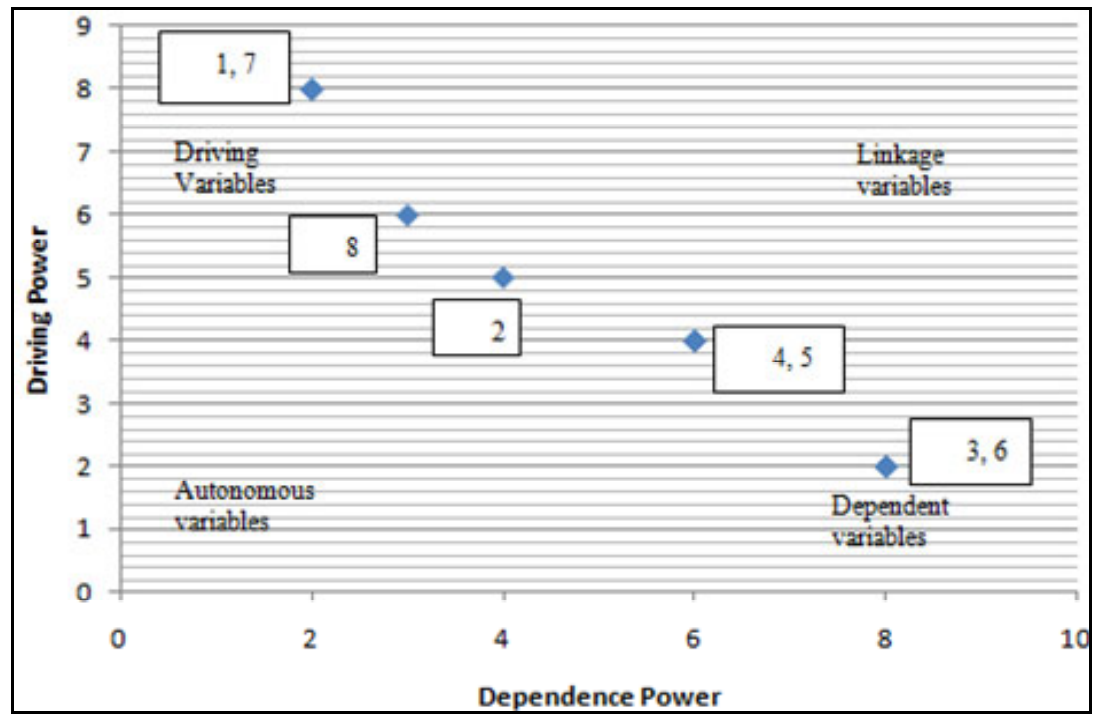

\section{Major contribution}

It was found that integrating sustainability with lean practices is becoming a strategic opportunity for the Indian manufacturing enterprises (Dixit et al., 2011). It was also discovered that the motivation that influence the firms to move towards integration of sustainability with lean practices is to have compliance with the regulations and this has compelled the corporations to green their processes and products.

It was also analysed that another reason that influences the corporations is the availability of financial resources. Therefore, it can be concluded that integration of sustainability with lean practices act as the enabler for the Indian manufacturing industries to enhance their opportunities and also to increase their potential (Dixit et al., 2011).

\section{Future scope}

The present research has drawn conclusions based on the establishment of the mental model . This mental model is constructed upon the opinion of the experts. The future scope lies in validating the results obtained by the ISM model with the results obtained by the application of the statistical technique like SPSS and SEM. 


\section{Conclusions}

Based upon the ISM model, it can be seen that financial factor and government rules and regulations have the maximum driving power. These drivers push the firms to incorporate environmental aspect into their operations and thus move in the direction of sustainable manufacturing.

\section{References}

Bergek, A., Berggren, C. and KITE Research Group (2014) 'The impact of environmental policy instruments on innovation: a review of energy and automotive industry studies', Ecological Economics, Vol. 106, pp.112-123, DOI: 10.1016/j.ecolecon.2014.07.016.

Cuerva, M.C., Triguero-Cano, Á. and Córcoles, D. (2014) 'Drivers of green and non-green innovation: empirical evidence in low-tech SMEs', Journal of Cleaner Production, Vol. 68, pp.104-113, DOI: 10.1016/j.jclepro.2013.10.049.

Dixit, A., Patel, S. and Dixit, A. (2011) 'Lean manufacturing to lean enterprises', Proceedings of the International Conference on Industrial Engineering, SVNIT, Surat.

Emiliani, M.L. (2001) 'Redefining the focus of investment analysts', The TQM Magazine, Vol. 13, No. 1, pp.34-51.

Fagerberg, J. (2005) The Oxford Handbook of Innovation, Oxford University Press, New York.

Haleem, A., Sushil, Qadri, M. and Kumar, S. (2012) 'Analysis of critical success factors of world-class manufacturing practices: an application of interpretative structural modeling and interpretative ranking process', Production Planning \& Control, Vol. 23, Nos. 10-11, pp.722-734 [online] http://dx.doi.org/10.1080/09537287.2011.642134.

Jones, J. and de Zubielqui, G.C. (2016) 'Doing well by doing good: a study of university-industry interactions, innovationess and firm performance in sustainability-oriented Australian SMEs', Technological Forecasting and Social Change, Vol. 123, pp.262-270, DOI: 10.1016/j.techfore.2016.07.036.

Khurana, S., Mannan, B. and Haleem, A. (2014) 'Integrating innovation with sustainability: a study of practices/status for Indian manufacturing industries (SMEs)', in AGBA's 11th World Congress, IIT Delhi, India.

Kumar, S., Luthra, S. and Haleem, A. (2013a) 'Customer involvement in greening the supply chain: an interpretive structural modeling methodology', Journal of Industrial Engineering International, Vol. 9, No. 1, p.6 [online] http://dx.doi.org/10.1186/2251-712x-9-6.

Kumar, N., Kumar, S., Haleem, A. and Gahlot, P. (2013b) 'Implementing lean manufacturing system: ISM approach', Journal of Industrial Engineering and Management, Vol. 6, No. 4 [online] http://dx.doi.org/10.3926/jiem.508.

Kunapatarawong, R. and Martínez-Ros, E. (2016) 'Towards green growth: how does green innovation affect employment?', Research Policy, Vol. 45, No. 6, pp.1218-1232.

Lecerf, M.A. (2012) 'Internationalization and innovation: the effects of a strategy mix on the economic performance of French SMEs', International Business Research, Vol. 5, No. 6, p.2.

Luthra, S., Garg, D. and Haleem, A. (2015) 'An analysis of interactions among critical success factors to implement green supply chain management towards sustainability: an Indian perspective', Resources Policy, Vol. 46, pp.37-50, DOI: 10.1016/j.resourpol.2014.12.006.

Mannan, B. and Khurana, S. (2012) 'Enablers and barriers for introduction of robotics as an AMT in the Indian industries (case of SME's)', International Journal of Computer Applications, Special issue, pp.19-24. 
Mannan, B., Khurana, S. and Haleem, A. (2012) 'Identification and analysis of critical factors of $\mathrm{KM}$ in project management: an interpretive structural modelling approach', XVI Annual International Conference of Society of Operation Management, Jointly hosted by IIT Delhi and IIM Lucknow.

O'Cass, A. and Weerawardena, J. (2009) 'Examining the role of international entrepreneurship, innovation and international market performance in SME internationalisation', European Journal of Marketing, Vol. 43, Nos. 11/12, pp.1325-1348.

Pedram, M. (2011) Lean Production: Introduction and Implementation Barriers with SME's in Sweden, School of Engineering in Jonkoping, Sweden.

Pingyu, A.Y. and Yu, B.Y. (2010) 'The barriers to SME'e s implementation of Lean production \& countermeasures', International Journal of Innovation, Management \& Technology, Vol. 1, No. 1, pp.148-151.

Subrahmanya, M.B. (2015) 'Innovation and growth of engineering SMEs in Bangalore: why do only some innovate and only some grow faster?', Journal of Engineering and Technology Management, Vol. 36, pp.24-40, DOI: 10.1016/j.jengtecman.2015.05.001.

Taleghani, M. (2010) 'Key factors for implementing the lean manufacturing system', Journal of American Science, Vol. 6, No. 7, pp.287-291.

Xie, X., Zeng, S., Peng, Y. and Tam, C. (2013) 'What affects the innovation performance of small and medium-sized enterprises in China?', Innovation, Vol. 15, No. 3, pp.271-286. 